\title{
ESPAÇO LIVRE - OBJETO DE TRABALHO
}

\section{OPEN SPACE}

Miranda Martinelli Magnoli

Professora titular da Faculdade de Arquitetura e Urbanismo da Universidade de São Paulo (FAUUSP).

E-mail:mmemm@uol.com.br

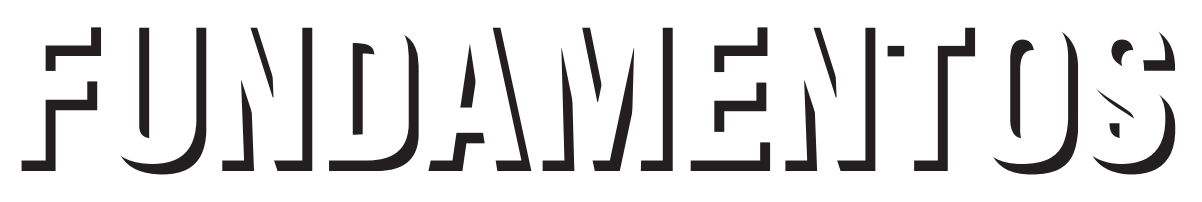




\section{RESUMO}

Este texto introduz conceitos básicos para o entendimento do Paisagismo - no caso, o de paisagem e espaços livres, aproximando-se em bibliografia específica e em sínteses elaboradas em decorrência de pesquisa efetuada sobre aspectos da paisagem metropolitana de 1979 a 1982. Divide-se em duas partes: Intervenção e Presença do Homem na Paisagem e Funções, Formas e Distribuição do Espaço Livre.

Palavras-chave: Espaço livre, paisagem, cultura, natureza.

\section{ABSTRACT}

This paper introduces two of the basic concepts of landscape architecture: landscape and open space. It was the result of an extensive research process developed between the years of 1979 e 1982. It's divided in two parts: the Landscape ant the Man and open Spaces: Functions, Forms and Distribution.

Key words: Open space, landscape, culture, nature. 


\section{ESPAÇO LIVRE - OBJETO DE TRABALHO}

\section{OPEN SPACE}

\section{Intervenção e Presença do Homem na Paisagem}

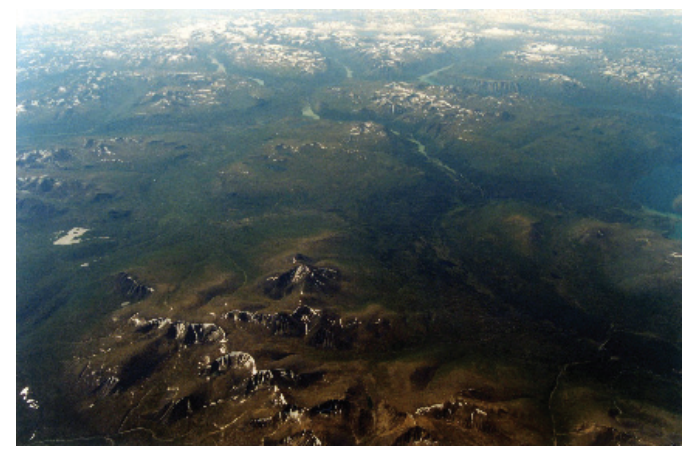

Foto A: Vista aérea - Montanhas nevadas no Alaska Crédito: Silvio Macedo, 2003

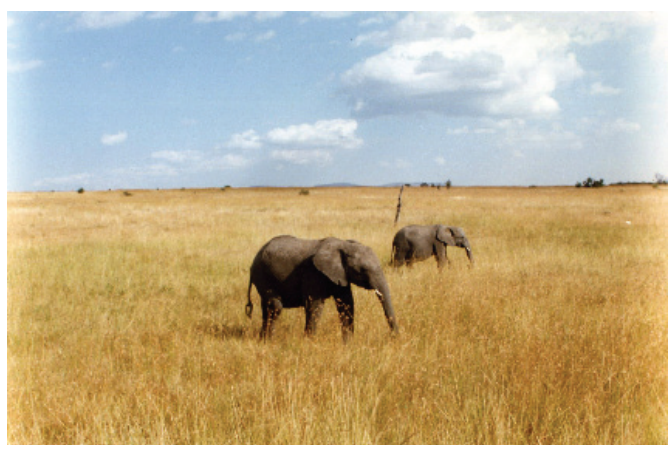

Foto A2: Elefantes na Savana - Parque Masai Mara, Quênia

Crédito: Silvio Macedo, 1997

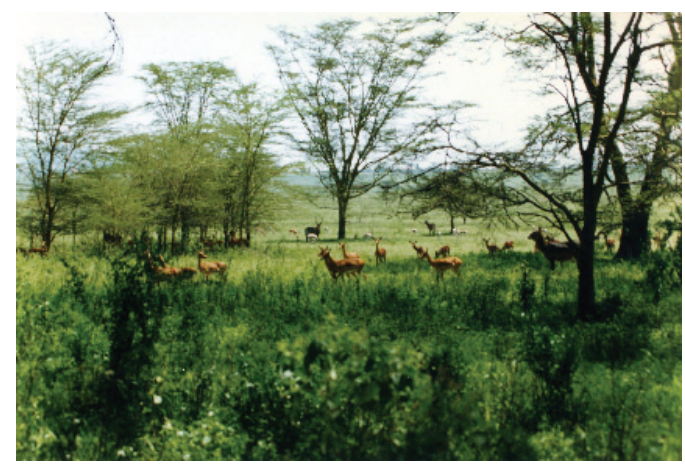

Foto A3: Parque Nacional, Quênia

Crédito: Silvio Macedo, 1997
O termo paisagem permite acepções as mais diversas: em sua complexidade envolve as mais variadas idéias; a acepção varia conforme a referência, a formação disciplinar. A ampliação de necessidades globais do homem estendeu o campo de conhecimentos. $O$ homem ampliou sua ação (criação de paisagens) sobre a Terra em graus maiores e em tecnologias as mais diversas. Em relação à intervenção antrópica podemos distinguir a presença do homem em:

- Paisagens derivadas quase diretamente do hábitat natural da região (florestas, desertos, etc.). As intervenções se deram, em geral, em épocas muito anteriores (devastação de florestas e erosão do solo na Europa, ampliação do Sahara no Sahel, etc.). São basicamente paisagens onde o homem está ausente ou a população humana é rarefeita e não vive de trabalho intenso na terra (ex.: caça, pesca ou áreas de lazer de uso transitório). Intervenções mínimas, facilmente reversíveis e pouca presença local do homem (Fotos A, A2, A3);

- paisagens deliberadamente mantidas. São os parques nacionais, grandes reservas, estações ecológicas, paisagens preservadas por sua "arquitetura" excepcional ou pela história e memória. A intervenção é reduzida; a presença do homem acontece principalmente na decisão da preservação e na gestão para manutenção da preservação com graus e tipos de usos compatíveis (Fotos B e C);

- paisagens de áreas altamente industrializadas cujo suporte de sobrevivência do homem é distante; a intervenção é reduzida (espacialmente), conforme o tipo de industrialização (mais habitual em países altamente desenvolvidos). A presença do homem no local é reduzida (Foto D); 


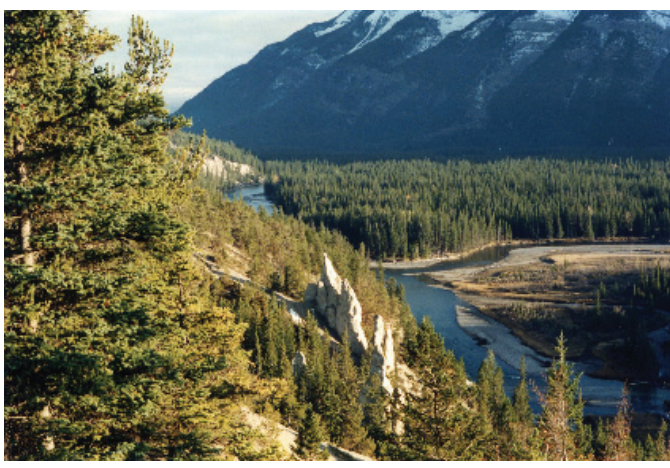

Foto B: Vista geral - Parque Nacional de Banff, Canadá Crédito: Silvio Macedo, 1994

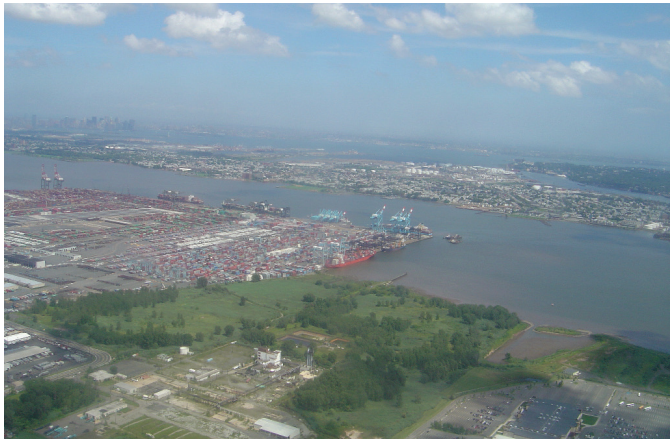

Foto D: Vista aérea - Área industrial em Nova Jersey, vizinha à Nova York, EUA

Crédito: Silvio Macedo, 2004

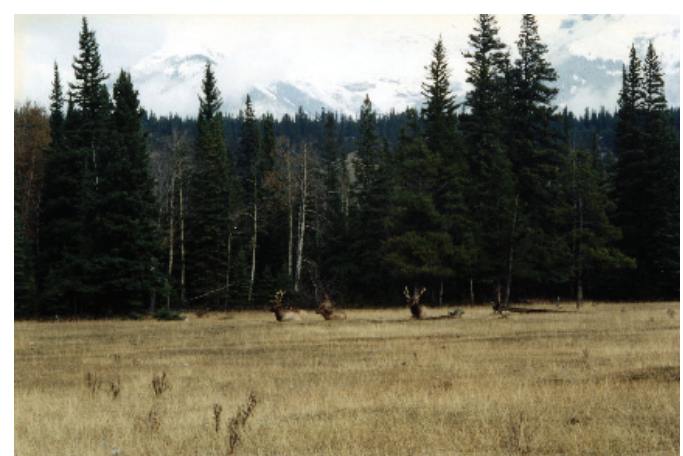

Foto C: Rebanho de renas, Parque Nacional de Banff, Canadá

Crédito: Silvio Macedo, 1994

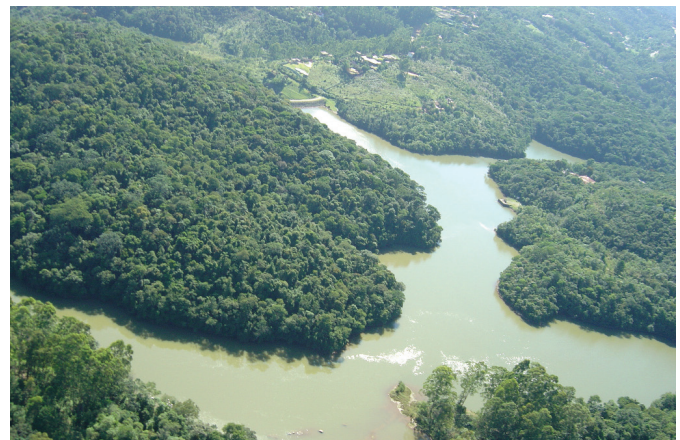

Foto E1: Vista aérea - Represa de Mairiporã

Crédito: Silvio Macedo, 2005

- paisagens sem parcela ponderável de população humana, mas altas e imediatamente funcionais. São fazendas de produção, áreas de mineração, áreas industriais e de serviços (barragens, reservatórios, portos, estradas, canais, aeroportos, etc.) Produções que, por suas características ou pela tecnologia empregada, dispensam mão-de-obra em quantidade e próxima, de forma permanente. A intervenção antrópica é freqüentemente intensa e/ou extensa, mas a presença local do homem é reduzida e/ou transitória. Os aspectos socioeconômicos interagem intensamente, de maneira imediata nas decisões sobre a intervenção (Foto E1);

- paisagens com parcelas ponderáveis de população humana de forma permanente. São os núcleos urbanos.

Poucas são as paisagens as quais não têm a intervenção do homem, mesmo que se apresentem preponderantemente com elementos da base natural da paisagem. A forma e a representação da intervenção são variadas, porém praticamente quase todas são criação do homem. A presença do homem, assentado, vivendo em determinada paisagem, em parcelas ponderáveis, de forma permanente é que se constitui na maior variável. Nessas a presença do homem faz com que todos os aspectos e valores referentes ao homem venham a emergir com o máximo de ênfase.

A morfologia da paisagem é a resultante da interação ente a lógica própria dos processos do suporte (sistemas geológico e climático) e a lógica própria dos processos sociais e culturais (antrópica). 
"A realidade não é (autentica) realidade sem o homem, assim como não é (somente) realidade do homem. É realidade da natureza como totalidade absoluta, que é independente não só da consciência do homem, mas também da sua existência, e é realidade do homem que na natureza e como parte da natureza cria a realidade humano-social, que ultrapassa a natureza e na historia define o próprio lugar no universo. $O$ homem não vive em duas esferas diferentes, não habita por uma parte de seu ser, na historia, e pela outra, na natureza. Como homem ele está junto e concomitantemente na natureza e na história. Como ser histórico e, portanto, social, ele humaniza a natureza, mas também a conhece e reconhece como totalidade absoluta, como causa sui suficiente a si mesma, como condição e pressuposto da humanização" (este grifo é nosso)..." em todas as variantes da posição humana diante da natureza, em todos os progressos do domínio e do conhecimento humano dos processos naturais, a natureza continua a existir como totalidade absoluta. Na industria, na técnica, na ciência e na cultura, a natureza existe para o homem como natureza humanizada, ..."1

A lógica própria dos processos do homem se apresenta por expressões físicas (parcelamentos, escavações, plantações, construções, edificações, etc.) em expressões físicas que apresentam a lógica dos processos do suporte (geologia e clima, solo, relevo, vegetação e sol, água e ventos).

Na paisagem urbana essas expressões físicas se manifestam sobre o solo em espaços edificados e espaços não-edificados. O espaço livre é todo espaço não ocupado por um volume edificado (espaço-solo, espaço-água, espaço-luz ao redor das edificações a que as pessoas têm acesso).

\section{Funções, Formas, Distribuição do Espaço Livre}

Aos espaços livres de edificação é habitual que se acoplem funções, passando a classificá-los. A classificação por funções é tarefa bastante complexa, já que não se auto-selecionam por funções. Por exemplo, Marion Clawson² indica:

" propiciar perspectivas e vistas do cenário urbano;

- propiciar recreação no mais lato sentido do termo, com amplo de atividades especificas;

- propiciar proteção ecológica a valores importantes, como recarga de água do subsolo, prevenção de inundações, preservação de áreas excepcionais e similares;

- servir como dispositivo ou influencia para a morfologia urbana, de tal forma que parte de um extenso aglomerado seja identificado de suas vizinhanças;

- reservar presentemente áreas sem utilização para usos futuros. A ênfase no caso não é tanto no uso atual, mas na manutenção para usos mais ativos posteriormente".

Faz-se indispensável citar a identificação de Tunnard-Pushkarev ${ }^{3}$ em quatro funções: produtiva, protetora, ornamental e recreativa ${ }^{4}$. Charles $\operatorname{Eliot}^{5}$ distingue espaço livre "de serviço" e espaço livre "estrutural". Stanley Tankel ${ }^{6}$ considera que a distinção básica ocorre a partir da tomada de consciência do indivíduo sobre o espaço: o indivíduo pode não estar consciente, porém afeta o cotidiano. E o indivíduo se apercebe em três formas: usando-o, vendo-o e sentindo-o. Exemplifica o uso nas atividades recreativas e na circulação; é uma das percepções mais costumeiras e preferenciais. Lembramos de vê-lo na rua, nas aberturas das edificações e de senti-lo especialmente nas situações de amplitude ou de isolamento ${ }^{7}$. $\bigcirc$ espaço "de serviço" ou aquele que participa do modelo de urbanização é raramente percebido (isso não justifica a falta de proteção para o abastecimento de água, para as inundações, para as pistas aéreas, para reservas, porém facilita bastante esta falta de proteção).

Na relação de Clawson observa-se, à primeira vista, que as funções de propiciar luz, ar, perspectivas e vistas são simultâneas. E simultâneas com o acesso às edificações (que sequer chega a ser citado). Muito freqüentemente está respondendo também às outras ou parte das outras. 
Na página seguinte encontra-se ${ }^{8}$ a classificação de acordo com as normas californianas. Essa visão tão organizada, particularizada e toda compartimentada deve dar a impressão inicial de, com esse instrumental, é só partir para o trabalho com uma bela coleção de "tinta mágica, se possível com 42 cores e... se ter um painel muito colorido!".

A sobreposição de funções, a ampla variação de escala e formas, a possibilidade de, no mesmo espaço, contar-se com utilizações diversas em tempos diversos, é flagrante?.

\section{Funções dos Espaços Livres Urbanos}

(Classificação de acordo com as normas californianas)

\section{Espaços Livres em Função da Produção de Recursos}

1.1 - Florestas explorativas

1.2 - Terras agrícolas

1.2.1 - com alto grau de fertilidade

1.2.2 - com culturas especiais

1.2 .3 - de culturas florais

1.3 - Zonas de extração de minerais

1.3.1 - minerais raros

1.3.2 - minerais utilizados localmente (saibros, pedras, etc.)

1.4 - Terrenos para pasto

1.5 - Terrenos importantes para recursos hídricos

1.5.1 - zonas de alimentação de lençóis subterrâneos

1.5.2 - lagos de vertentes

1.5.3 - barragens para a adução de água

1.5.4 - barragens para a produção de eletricidade

1.6 - Zonas de produção de vida aquática (brejos, zonas inundáveis) para fins comerciais ou lazer

\section{Espaços Livres Para Proteção de Recursos Naturais e Culturais}

2.1 - Águas em todas as suas formas, brejos, pântanos servindo de habitação à forma aquática

2.2 - Bosques e florestas para reservas naturais

2.3 - Características geológicas

2.3.1 - penhascos, promontórios, rochedos excepcionais específicos

2.3.2 - zonas de deslizamento

2.3.3 - zonas de conformações ou formações especiais

2.4 - Locais de monumentos históricos ou culturais

2.4.1 - locais classificados pela história

2.4.2 - locais parte da memória

2.4 .3 - paisagens agrárias excepcionais

\section{Espaços Livres, Sanitários e Sociais}

3.1 - Zonas de proteção das águas subterrâneas (trabalha com 1.5.1 e 2.1)

3.2 - Zonas de depósito de lixo

3.3 - Zonas de regeneração de ar (conformações topográficas ou florestas)

3.4 - Zonas de lazer

3.4.1 - jardins e praças públicas de quarteirões

3.4.2 - parques urbanos nos vários níveis 
3.4.3 - parques regionais e outras áreas de reserva, etc., que podem ser utilizadas com essa fertilidade

3.5 - Zonas de deslocamento para o lazer

3.5.1 - circulação, pistas para ciclistas, equitação, etc.

3.5.2 - estradas turísticas

3.5.3 - rios e canais navegáveis

3.6 - Zonas de pontos de vistas notáveis

3.6.1 - morros, vales, flancos e colinas, lagos capazes de propiciar prazer visual em oposição à paisagem artificial das cidades

3.6.2 - morros propiciando panorama excepcional

3.6.3 - espaços que propiciam variedade, enriquecimento e ruptura na paisagem edificada densa ou excessivamente homogênea

3.7 - Zonas para controle e guia do crescimento urbano

3.7.1 - capazes de permitir identificação das aglomerações urbanas

3.7.2 - assegurando separação entre usos do solo (incompatíveis)

\section{Espaços Livres Para Segurança Pública}

4.1 - Barragem de controle de zonas de inundação, zonas situadas na área de influências de barragens

4.2 - Zonas de solo instável

4.2.1 - por deslizamento

4.2.2 - por declives acentuados

4.2.3 - por sobrevôo de aeroportos

4.2 .4 - por riscos de incêndio

\section{Espaços Livres-Corredores}

5.1 - Linhas de alta tensão

5.2 - Canais e canalizações diversas

5.3 - Vias rodoviárias e ferroviárias

\section{Espaços Livres Para extensão Urbana, Zonas Para Comércio, Indústria, Habitação, Equipamentos Públicos, etc.}

"O trabalho do profissional que atua em paisagismo tem se desenvolvido preponderantemente em espaços que pelos códigos são definidos como espaços necessários para a insolação e acessos as edificações: são os recuos de frente, lateral e fundos. No desenho urbano os espaços são aqueles definidos pelo sistema viário e por uma reserva de outro espaço livre, devidamente classificado em 'de recreação' ou 'área verde' que se define por uma porcentagem. Nas principais avenidas se espera estar entre 'boulevards copados' desde que as árvores se plantadas e mantidas cresçam sobre um solo composto de tubulações diversas da infra-estrutura. É preciso que se saiba o que realmente se quer e se pode ter. Exige-se a criação de topoclimas em locais de maior uso, a diminuição de índices de ruído, a correção de erros de intervenção no relevo, a garantia de limpeza das águas, a capacidade de atuarem como focos de promoção social; o atendimento a níveis e graus de recreação os mais diversos. A um equipamento raríssimo se fazem exigências funcionais intensas e extensas independente de desacertos no uso do solo e de qualquer política de espaços livres."

A especificidade funcional ao espaço livre é, às vezes, exigida para algumas atividades; ela é, porém, freqüentemente atribuída (ou imposta) desnecessariamente (ou quiçá porque) por desenho (um gramado pode propiciar muito mais do que uma "pelada"; contudo se desenha uma 
"quadra", devidamente cercada, com tela, portão e piso devidamente igual em toda a periferia, (sempre com 2 metros de largura!). Saudavelmente, os arquitetos estão descobrindo que "vamos ter que aprender daqui para frente, a trabalhar com aberturas e com espaços em branco de significados" ..." sejam saudavelmente abertos e saudavelmente ambíguos, para que permitam uma criação ampla de significados"10.

A forma do espaço livre é mais um elemento vago, variável, indefinido a priori. A também freqüente classificação dos espaços livres relacionando funções com superfícies de maneira apriorística é extremamente discutível (da menor à maior superfície correspondendo de playlot a "parque metropolitano"). A superfície, a dimensão, "o tamanho" de um lugar é relacionado especialmente ao tipo de utilização que pode propiciar. Forma e desempenhos diversos (a mesma superfície da "quadra" em um espaço preponderantemente linear sugere uma série de outras atividades que não a "pelada"; e, aliás, uma série delas será mais gostosa em um espaço linear).

Em geral, um dos papéis mais atribuídos ao espaço livre é o de propiciar recreação. Às atividades de "não-trabalho" corresponde um espectro variado e diversificado que não tem nada a ver com os eventuais equipamentos que venham a ser, eventualmente, postos em um lugar.

Compatibilização de funções no tempo e no espaço; formas, superfícies e tratamentos diversificados, segurança (de desenho), conforto, adequação às condições do tempo, desenho apropriado à manutenção, localização e acessibilidade não podem ser substituídos por uma coleção de equipamentos, por mais bem desenhados que sejam.

Todavia, à forma, por mais variável e indefinida que seja, corresponde uma existência física, material, concreta do espaço. E essa configuração física dos espaços livres de edificações remete-nos automaticamente à distribuição das edificações e dos espaços livres. À ocupação de um mesmo espaço pelas mesmas edificações em diferentes arranjos correspondem diferentes configurações físicas do espaço livre. A diferentes configurações físicas correspondem diferentes oportunidades, alternativas, "espaços" (compreendidos da forma mais aberta possível). Diferentes configurações físicas do espaço livre são, nessa reflexão, dependentes da distribuição do espaço edificado. A distribuição do espaço edificado pode, e o faz, a partir de uma mesma quantidade, criar uma configuração tal ao espaço livre, que propicie muito ou limite extremamente (isso não acontece aleatoriamente; e, quando a megalomania e o etnocentrismo tomam conta do arquiteto da edificação, só muito excepcional e acidentalmente, sem que ele o perceba, é que o espaço livre propicia muito). (Desenho)

Na medida em que as edificações e os conjuntos de edificações se distribuem pelas várias escalas, desde o lote à região, automaticamente definem, nas várias escalas, as configurações físicas do espaço livre, desde o lote à região ${ }^{11}$.

Por outro lado, as configurações em uma determinada escala influenciam pelas configurações nas demais escalas.

Uma configuração é diversa se examinada isoladamente, em uma escala ou se examinada em outra escala: comporta-se diversamente para cada uma das escalas.

Vistos e desenhados isoladamente, edifícios e espaços livres são fragmentos. $\bigcirc$ que existe são estruturas ambientais as quais são fundamentalmente, no físico, configurações de espaços edificados e livres em uma certa forma de integração.

A qualidade do espaço urbano, um dos fatores da qualidade de vida urbana, é seriamente influenciada pela configuração física do espaço livre: como pode ser simplesmente decorrente do desenho do espaço edificado? $\bigcirc$ espaço livre público é o espaço da vida comunitária por excelência. $O$ espaço edificado público é só eventualmente tão público quanto o espaço livre público. 

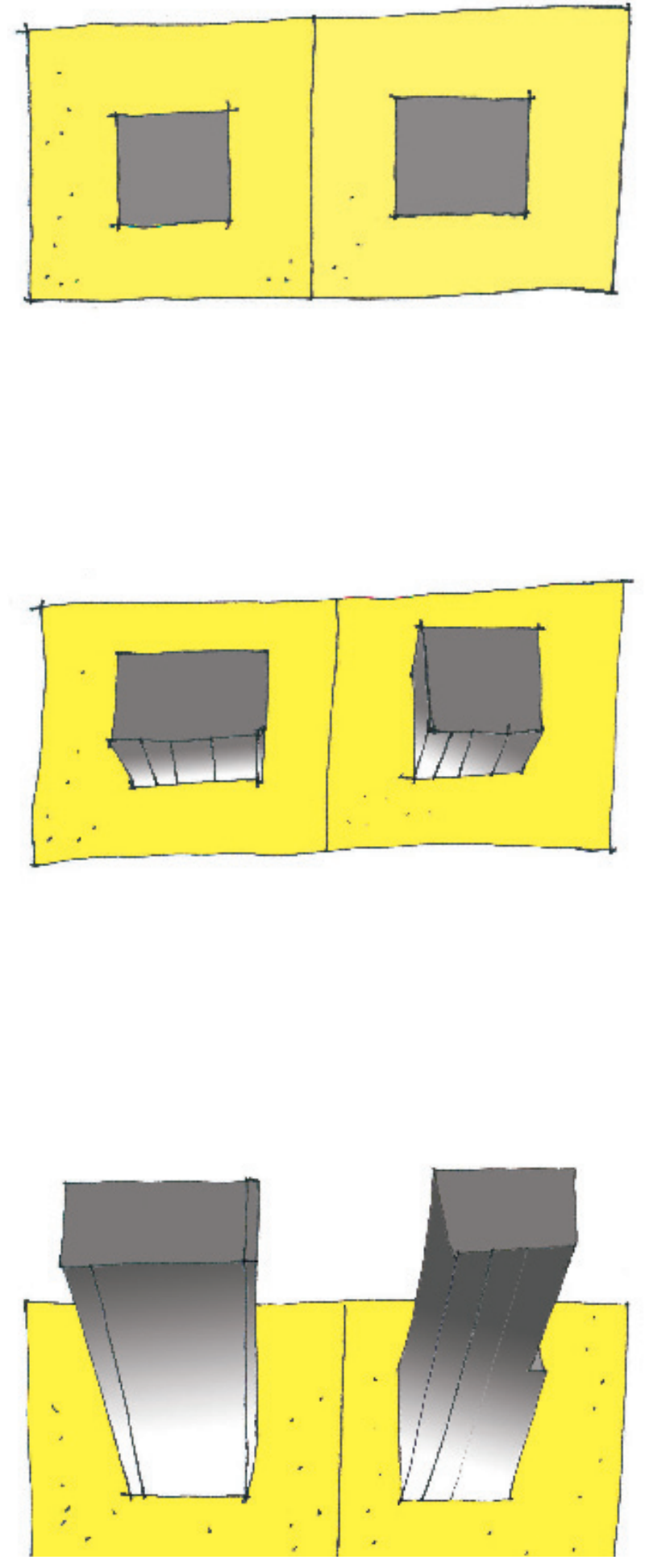

O espaço livre não pode ser avaliado bidimensionalmente somente, pois esta escala mascara sua real volumetria e forma Crédito: Silvio Soares Macedo
Em qual medida somos capazes de avaliar as diferentes alternativas de configurações físicas nas várias escalas do tecido urbano e do território? E nas inter-relações de escalas? Em que medida, somos capazes de, nas alternativas, procurar aliar os requisitos da intervenção antrópica às oportunidades e limitações do suporte? Em que medida somos capazes de fazer com que os efeitos derivados, os quais deveriam ser só secundários, não se transformem em uma "questão ambiental" ? ${ }^{12}$. É possível cada uma das partes, respeitadas suas especificidades, ocupando seu lugar, no tempo e no espaço, no processo, produzirem e reproduzirem a totalidade?

\section{Aspectos Preliminares do Espaço Livre na Escala da Rua}

É o espaço livre associado às edificações; O espaço do cotidiano, o que afeta diariamente nossas vidas, dentre os demais espaços livres, é o que tem maior grau de intervenção antrópica. No modelo de urbanização tem predominância qualitativa e quantitativa. É subordinado às atividades dos usuários e aos edifícios de seu entorno. Essa subordinação nos leva a observações quanto às edificações; selecionamos as edificações habitacionais, já que no modelo urbano correspondem à função que supera de muito todas as demais funções e também é a que está ligada a toda a população urbana. Os aspectos levantados dizem respeito às relações do espaço livre com o modelo urbano em particular, onde e como é encontrado, relegando-se o quanto para as situações as quais se refletem no onde. Do ponto de vista da utilidade social foi considerado que onde e como possuem um papel mais relevante que a quantidade. A questão é levantada sob a preocupação da "produção" e distribuição do espaço livre, estreitamente vinculada à edificação e à urbanização em seus prognósticos. Preliminarmente, é indispensável levantar alguns aspectos relativos à distribuição de áreas no espaço edificado habitacional.

Desconheço um inventário da edificação habitacional em São Paulo que possa indicar distribuições de área por pessoa no volume edificado habitacional. Pushkarev ${ }^{13}$, ao fazer referência a Manhattan em Nova York, indica uma média de $30 \mathrm{~m}^{2}$ por pessoa, variando próximo de 
$20 \mathrm{~m}^{2} /$ pessoa em conjuntos habitacionais de faixa de renda menor para pouco mais de 42 $\mathrm{m}^{2}$ para as faixas de renda mais alta. Segundo o autor, a média estaria próxima das recomendações da American Public Health Association; em referência a alguns outros países poderia ser constatado que o grande volume de construções posteriores à Seguna Guerra Mundial na Europa Ocidental alocava, em geral, a ordem de $25 \mathrm{~m}^{2}$ por pessoa. Em Moscou a superfície

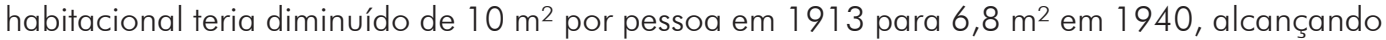
$13,5 \mathrm{~m}^{2} \mathrm{em} \mathrm{1970}{ }^{14}$. A falta de levantamentos especificamente executados com essa finalidade para São Paulo, apoiada na vivência longa de atividade como arquiteta, no acompanhamento de estudos de casos de colegas docentes e alunos, constato que a amplitude de variação da superfície por pessoa, na edificação habitacional em São Paulo, é muito grande. Para as faixas de renda menor é bastante difícil que se alcance a dezena de metros quadrados por pessoa, e para as faixas de renda alta facilmente se alcança de 80 a $100 \mathrm{~m}^{2}$ por pessoa. A partir desses valores como extremos, qualquer média não tem o menor significado; e, não há duvida que, nesse amplo leque, a relação mais predominante está sempre mais próxima do valor inferior e extremamente distante do superior. Ao se observar relação de aproximadamente 2.5 vezes entre os extremos de Manhattan, os quais os autores, aliás, consideram substanciais, chama particular a atenção a disparidade de nossos extremos, por volta de 10 vezes, mesmo que se leve em conta os possíveis acréscimos que a população de baixa renda vai executando com o passar dos anos no reduzido lote. Sem dúvida, os diferentes contextos se apresentaram nos vários índices exemplificados pelos autores em outras cidades, em diferentes épocas; dificilmente, porém, há contexto, cidade ou época a justificar a amplitude de 10 vezes entre extremos. Quaisquer que sejam as distribuições das áreas edificadas será necessário serem associadas, nos aspectos da paisagem urbana, à distribuição no solo, incorporando o espaço livre adjacente às edificações, seja ele particular ou público, individual ou comunitário. (Foto F)

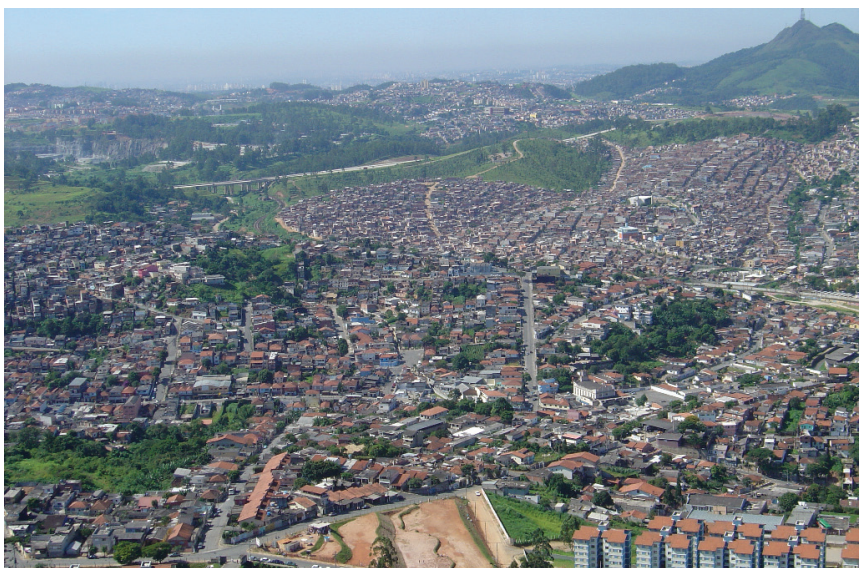

Foto F: Habitação popular em São Paulo, com seus espaços livres privados reduzidos Crédito: João Rett Lemos, 2005

\section{O Espaço Livre da Unidade Habitacional}

Sem dúvida, o abrigo primitivo se constituiu pela unidade edificada (ou cavada) isolada, isto é, com espaço livre em todo o seu entorno. O papel essencial era o de proteção, seja às condições do tempo ou a outros homens e a animais. Também servia de depósito de alimentos, utensílios e ferramentas e, às vezes, de animais domésticos; essa prática, em alguns lugares, continua até a época atual ${ }^{15}$. Um único e simples espaço com um acesso e, eventualmente, também outra abertura de ventilação, era o suficiente para a habitação primitiva. As formas evoluíram, ampliaram-se e diversificaram-se com as maiores complexidades da vida, o aumento das famílias e das exigências. $\bigcirc$ agrupamento de núcleos familiares ou tribais formou comunidades isoladas compostas de várias unidades. Essa nova relação, ao limitar a expansão das unidades, deve ter considerado de maior interesse a comunidade ao isolamento. Exigia avanços não só dos processos construtivos como das experiências da vida. Por mais variadas as formas sociais 
e de organização dos povoados, alguns conceitos básicos seriam identificados, "relação com o ambiente, composição organizada da cidade, importância dos espaços negativos, unidade de habitação, edifícios excepcionais, apropriado uso dos materiais e detalhes"16. (Foto G)

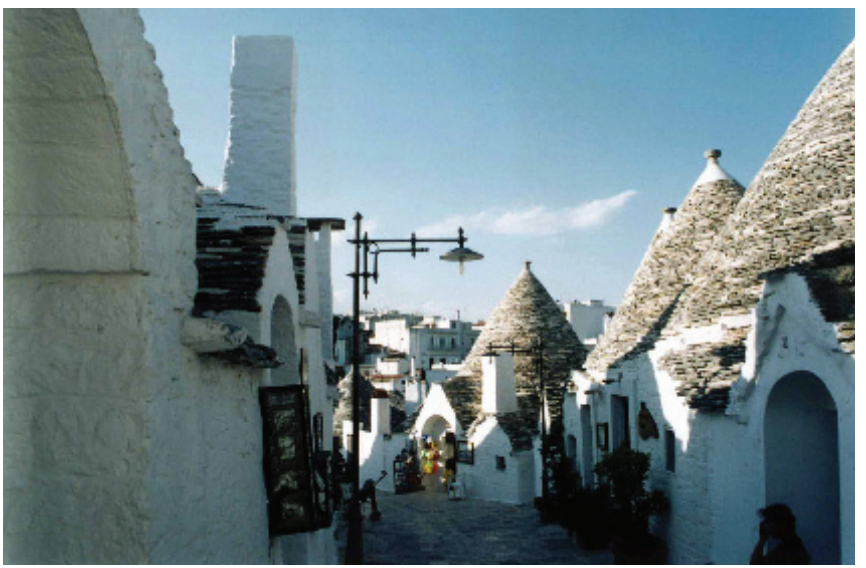

Foto G: Albero Bello (Itália) guarda, no século XXI, antigas estruturas residenciais comunitárias

Crédito: Silvio Macedo, 2003

Em São Paulo, no lote urbano colonial, são... "as casas térreas e sobrados construídos sobre alinhamento das vias públicas e sobre os limites laterais dos terrenos"17. E, também do mesmo autor: "não havia meio termo; as casas eram urbanas ou rurais, não se concebendo casas urbanas e com jardins. De fato, os jardins, como os entendemos hoje, são complementos relativamente recentes, pois foram introduzidos nas residências brasileiras durante o século XIX". O espaço livre particular adjacente à edificação era situado na parte posterior, em relação à rua, caracterizando-se como quintal, pomar, "fundos" e também recebendo parte das águas pluviais... "Cuja absorção pelo terreno ficava garantida pela extensão do mesmo"18. No período colonial o espaço livre adjacente à habitação realmente valorizado era o da própria chácara, já que este era o local de moradia. Observa Reis Filho que a iluminação e aeração eram garantidas por "aberturas dos cômodos de permanência das mulheres e dos locais de trabalho". O espaço livre particular adjacente à edificação viria aos poucos a isolar o volume edificado no lote, às vezes por espaço extremamente reduzido em uma das laterais, no final do século XIX. Dir-se-ia, então, que "por volta dos últimos anos do séc. XIX e início do século XX antes de 1914 podia-se considerar como completa a primeira etapa da libertação da arquitetura em relação aos limites dos lotes. Fundiam-se desse modo, duas tradições: a das chácaras e a dos sobrados" ${ }^{\prime 19}$. (Fotos H)

O espaço livre particular adjacente e isolando a edificação habitacional nas grandes cidades européias e americanas do começo deste século se difunde, especialmente, devido aos veículos
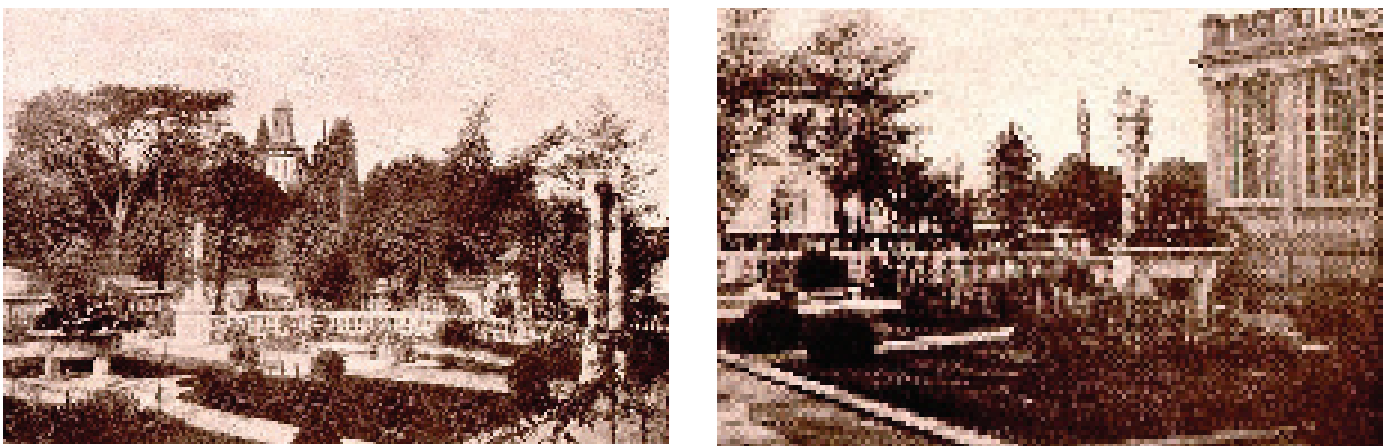

Fotos H: Jardins na avenida Paulista, segunda década do século XX.

Fonte: Dieberger, arte e jardim.

Arquivo: Silvio Macedo 


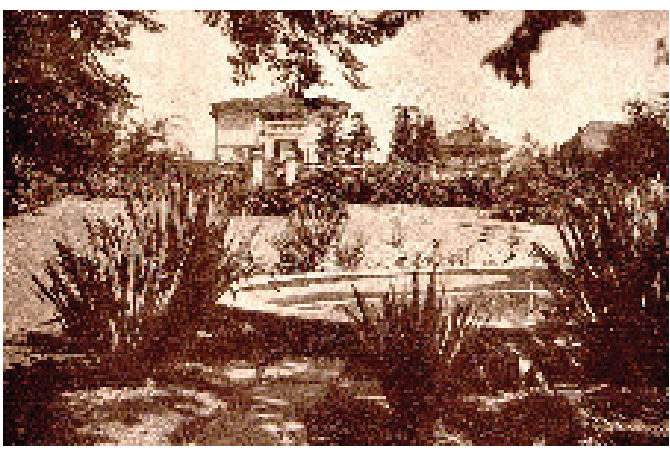

particulares que facilitam maiores deslocamentos, levando as famílias mais abastadas para as periferias. Quanto maior o espaço livre particular, mais oportunidades oferece de garantir reserva, isolamento (privacy) em relação aos habitantes das edificações próximas. Naquele lote americano do início do século com testada aproximada de $9 \mathrm{~m}$ havia muito mais espaço livre do que na morada anterior de Manhattan. Como edificações isoladas, as construções poderiam ser menos custosas, já que permitiriam o uso da madeira sem os perigos do incêndio, e os recuos laterais permitiriam mais aberturas. Porém, esse espaço livre seria um espaço fragmentado em frente, lateral e fundo, de modo sempre reduzido, e, a proximidade das janelas entre vizinhos certamente não traria a tão almejada privacy. Seriam seguidas estratégias para garantir maiores superfícies de lotes, especialmente maiores larguras por meio de loteamentos com zoneamentos específicos ${ }^{20}$. Conforme a solução da edificação, também a independência e reserva entre os indivíduos da família pode ser maior em maiores superfícies de lotes. Contudo, concomitantemente, diante das distâncias dos serviços urbanos, é decorrência e obrigatoriedade deslocamentos maiores e mais organizados para os locais de trabalho, escolas, abastecimento, diversão, encontros, etc. ${ }^{21}$ (Foto I)

Em qualquer lugar do mundo a casa utilizada no campo é, costumeiramente, a individual isolada: por todo o perímetro da edificação estende-se o espaço livre particular adjacente; em cidades, sua difusão e peso numérico no acervo habitacional são variáveis no tempo e nos diferentes lugares. A existência de espaços livres particulares no entorno da habitação só pode ser compreendida desde que a edificação e seu entorno adjacente constituam um aspecto único da habitação, uma unidade composta de interior-exterior.

A existência desse espaço livre só pode ser compreendida se o morador pode conferir-lhe atributos no contato com o espaço público (da rua, da praça, da viela, do pátio, etc.) na maior reserva de sua individualidade na habitação, na inclusão desse espaço livre como integrante da habitabilidade.

As relações entre o interior-exterior são baseadas na estrutura da planta da edificação, na distribuição e organização dos aposentos, nas aberturas para o espaço livre, seja o particular, seja o público.

É de supor que haja uma relação entre o espaço da unidade, seu desenho e as características do grupo familiar.

À habitação é conferido o máximo de oportunidades para valorização das especificidades individuais. $\bigcirc$ indivíduo escolhe, seleciona as demais pessoas que farão parte do grupo com as quais vai se relacionar mais próxima e constantemente; ele estipula características e condições da relação, do vínculo. Esse grupo, familiar ou não, é o que estipula as características de habitabilidade nas quais o espaço livre cumpre o papel de transição com o coletivo; daí a importância do papel do espaço no entorno perante a relação de socialização que the corresponde. 
O urbano, ao acentuar as oportunidades de sobreposição do espaço para grandes variedades de diferentes formas de relação entre os indivíduos e o coletivo, exige do desenho desse espaço o desempenho correspondente.

Atualmente, em São Paulo, o espaço do lote, o espaço da unidade interior-exterior pode ser encontrado em faixas extremas de centésimo de hectare e até meio hectare. Às vezes, sem dúvida, excepcionalmente, é possível encontrar mais de meio hectare inserido na mancha urbana. Não é excepcional a unidade de um centésimo de hectare: é habitual nas habitações de promoção oficial. Em grande parte da área contínua urbana são comuns os lotes ente 0,02 ha. e 0,04 ha.

No espaço da edificação já se havia observado que a média não teria qualquer significado. No espaço da unidade a questão recrudesce porque a variação entre extremos pode atingir até 50 vezes, e a variação de 6 a 10 vezes não é excepcional. Também o espaço exterior da unidade é especialmente maior nos casos em que é mais alta a superfície de edificação por pessoa.

O espaço exterior de um lote de dimensões reduzidas é um espaço fragmentado e estanqueizado em superfícies de dimensões e proporções tais, que fica extremamente limitada à utilização; as relações com os aposentos da edificação são muito prejudicadas; o isolamento e a reserva, em relação aos vizinhos, é muito discutível.

A arquitetura moderna favoreceu as oportunidades de utilização do espaço livre particular adjacente às habitações. "A possibilidade de se criar novas formas visuais no jardim, novas texturas, novas proporções em dimensões totalmente diversas do jardim dos séculos anteriores ('villas' italianas, palácios franceses, ingleses, japoneses) era vista na época com interesse na medida em que complementaria o cenário onde se deveria assentar a obra do arquiteto"22. A atividade do profissional atuando em espaços livres teve predominância de mercado de trabalho em unidades habitacionais nas quais o volume edificado era, em geral, livre dos limites do lote. Por outro lado, "a prática profissional era o elemento fundamental que alimentava o ensino das Faculdades; os estágios em escritórios profissionais eram considerados essenciais na formação, com papel insubstituível"23.

O motivo que leva parcela considerável da população à escolha dessa modalidade de moradia não pode ser o desempenho relativo aos atributos mencionados anteriormente. A necessidade básica de dispor de alguma habitação conjugada às circunstâncias de custos do terreno e edificação limita extraordinariamente as opções. Essa casa unifamiliar urbana de agrupamentos em formações cerradas nas quais superfícies descobertas só existem de forma marcadamente reduzida, não pode ser pretendida similar à unidade interior-exterior da "arquitetura dos arquitetos". E essas superfícies descobertas em que se valorizam a imagem e herança do termo árabe "carmen" (fusão de casa e jardim), ou "éden" (prazer, deleite) ou "átrio", ou "pátio" não têm e nunca tiveram relação com aquele espaço (qualquer seja o nome: quintal, fundos, jardim, ou outro) da habitação que, em qualquer época, forma social ou organização de cidades, tenha sido utilizada pela maior parte dos habitantes urbanos. $\bigcirc$ aumento da dimensão do lote, pelo acréscimo junto da edificação, do espaço livre (particular) aumenta as distâncias dos vizinhos e sem dúvida poderá conferir atributos de reserva, isolamento, habitabilidade, status, e lindos jardins. Conforme o número de unidades desse tipo e a quantidade de solo ocupado para essas unidades, a distância dos equipamentos urbanos pode ser acrescida desmesuradamente. Essa amplitude, "essa reserva", se desejável, obtida por meio de separação espacial, resulta em: o que pode ser bom para as (ou para algumas) famílias pode ser um absurdo como princípio para um assentamento urbano de considerável população.

\section{O Espaço Livre de Habitações Agrupadas}

Um dos aspectos mais representativos da paisagem urbana é a multiplicação em larga escala das habitações. Essa multiplicação se dá por agrupamentos; podem se desenvolver em 
qualquer dimensão: de algumas centenas de metros quadrados a centenas de hectares. $\grave{A}$ expansão de escala passa-se da relação edificação x espaço livre ou unidade interior $x$ exterior para modelos mais complexos e agrupamentos múltiplos em que a relação é de arquitetura x planejamento urbano x planejamento dos espaços livres. E... "se exigem considerações de uma totalidade formada por várias entidades, totalidade essa que não é a mera somatória das entidades mas uma integração dinâmica de entidades individualizadas; no espaço livre, o potencial de atividade se rebate diretamente na qualificação física e no caráter coletivo do agrupamento".

Os agrupamentos podem ser por adição na horizontal, na vertical, combinações de ambos por conformações as mais diversas. Os adensamentos têm uma situação limite no caso da associação horizontal e pouco limitada na combinação horizontal-vertical.

O desenho do agrupamento é responsável pela configuração física que propicia condições de organização da vida coletiva. Muito mais que a quantidade é o desenho da distribuição, a forma associada às atividades da função habitacional. Esse desenho é aquele que identifica os valores conferidos ao cotidiano da habitação na vida associativa urbana atual.

\section{Tecido Urbano ${ }^{24}$}

Entendemos o tecido como organização de elementos urbanos cujo conjunto constitui uma zona urbanizada. Selecionamos alguns aspectos do tecido que nos permite dar início à observação dos espaços livres nos tecidos urbanos.

aspecto que indica maior ou menor existência de espaços livres de edificações diz respeito à "contigüidade" dos volumes edificados. A contigüidade permite penetração do espaço livre: quanto de penetração é função do espaçamento entre os volumes. $\bigcirc$ aprofundamento e particularização do aspecto da contigüidade levantariam os dimensionamentos dos volumes edificados (intensidade de utilização do solo taxa de ocupação) e as formas dos volumes, definindo as formas dos espaços livres. No entanto, limitamo-nos a observar que o estabelecimento de graus, ainda que grosseiros, de contigüidade, permite tenhamos idéias preliminares de graus de existência de espaços livres. (Foto J)

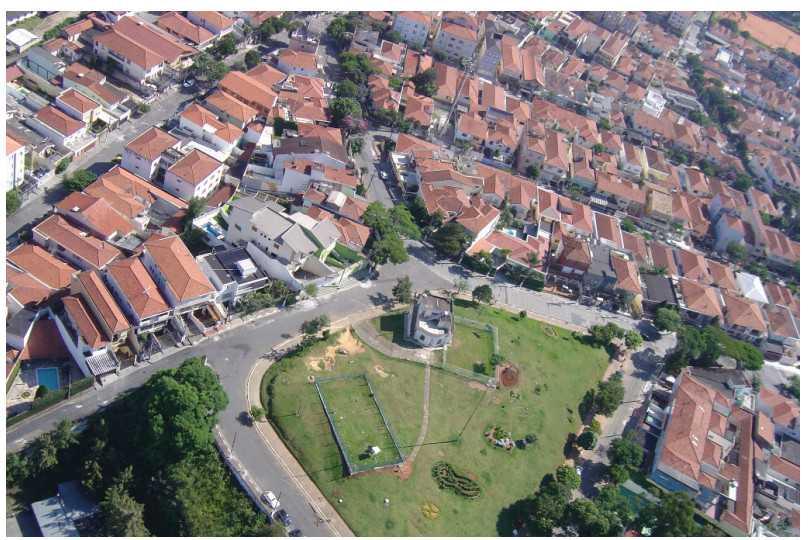

Foto J: Vista da rua Carlos Webbe, São Paulo Crédito: Solange Aragão, 2004

Adotamos os graus utilizados pelo estudo inicial que nos serviu de subsídio: contíguos, medianamente contíguos, descontíguos. A altura das edificações indica probabilidade de maior número de pessoas e possibilidade de variedade de funções. É importante observar que a altura das edificações não altera a existência de espaço livre. Altera caracterização, qualificações. Exigências, porém não altera o fato da existência. Será subsídio para o tipo e as características. Muito provavelmente o desenho deverá levar em conta o atendimento a uma maior complexidade funcional de atividades (dependendo do tipo, número e grau de diversificação de funções dos 
edifícios em relação às solicitações feitas aos espaços livres). Na maioria dos casos a maior altura das edificações significa maior número de pessoas e diferentes formas de acesso e transporte; a complexidade funcional no espaço livre será, em geral, variável e diversificada no tempo, em curtas durações e durações prolongadas. A diversidade de funções não é, contudo, uma especificidade da variação de altura nas edificações: está ligada ao contexto urbano em suas várias escalas.

Os dois aspectos, básicos na tipologia do tecido urbano, não têm influência sobre a acessibilidade ao espaço livre. Caracterizam existência, graus de existência, graus de complexidade, requisitos, enfim, elementos para o desenho, porém não estipulam tipo de penetração:

- Penetração física com deslocamento livre (independentemente da propriedade), com deslocamento restrito (algum tipo de controle): espaço acessível;

- penetração visual, sem penetração física: espaço visível, não-acessível;

- penetração da percepção: espaço perceptível, não-visível.

As caracterizações dos espaços quanto às possibilidades de penetração influenciam o tratamento dos espaços livres.

Para o objeto delimitado no presente estudo interessa-nos especialmente os espaços acessíveis e não-acessíveis, do ponto de vista de penetração física e que, simplificadamente, temos indicado como públicos e particulares. Ressalvamos os casos de espaços públicos, mas com acessibilidade restrita.

É evidente estarem relacionados a esses aspectos o parcelamento dos lotes, na média, no máximo, no mínimo e a densidade, taxa de ocupação, propriedade e apropriação do solo.

Esses elementos nos permitiram utilizar (somente como facilidade operativa) o zoneamento já que, de certa forma, qualifica os tecidos urbanos em relação com parte desses elementos. Realizamos uma série de levantamentos urbanos de áreas nas quais se adotou como um dos critérios iniciais de seleção a implantação de "ruas de lazer"25. Os levantamentos incluíram áreas de extensões diversas tendo sempre a "rua de lazer" inserida, na medida em que esta implantação indicaria necessidade de espaço livre para utilização pública. Os levantamentos ocorreram em diferentes zonas a fim de observar-se as demais características.

Indicamos, a seguir, alguns exemplos dos levantamentos:

ALTURAS

(em pavimentos)

FUNÇÕES:

ESTADO DE CONSERVAÇÃO:
Fotos L:

1 a 2 amarelo $\quad 9$ a 16 marrom claro

3 a 5 laranja

6 a 8 vermelho

Residencial : amarelo

Comercial : azul claro

Institucional : azul escuro

Industrial : rosa maravilha

Bom : lilás

Regular : azul

Ruim : roxo

ACESSO: $\quad$ Público : verde escuro

Particular: verde 

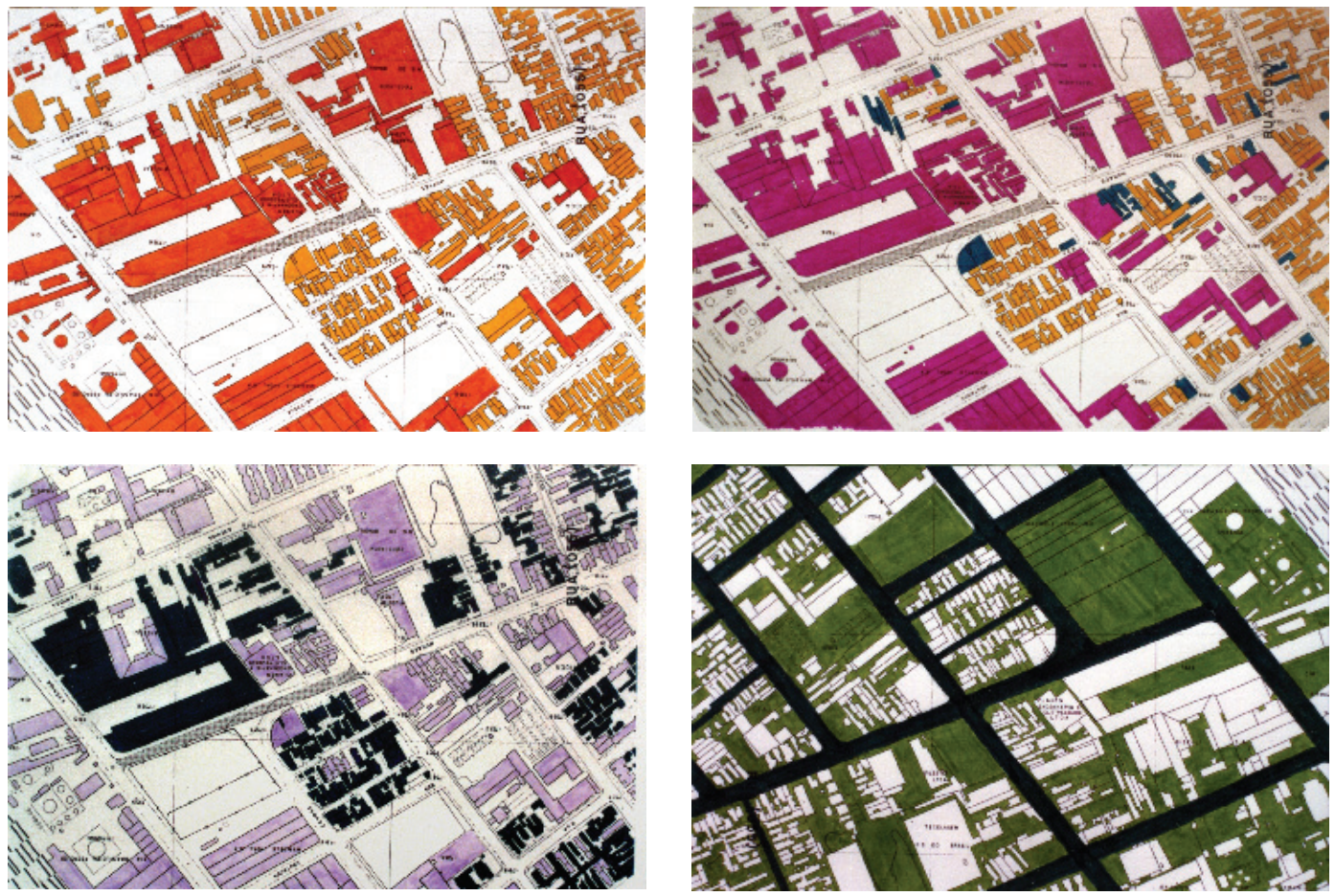

Fotos M:
ALTURAS
(em pavimentos)
1 a 2 amarelo
9 a 16 marrom claro
3 a 5 laranja
+16 marrom escuro
6 a 8 vermelho

FUNÇÕES:

Residencial : amarelo

Comercial : azul claro

Institucional : azul escuro

Industrial : rosa maravilha

ESTADO DE

CONSERVAÇÃO:

Bom : lilás

Regular : azul

Ruim : roxo

ACESSO:

Público : verde escuro

Particular: verde
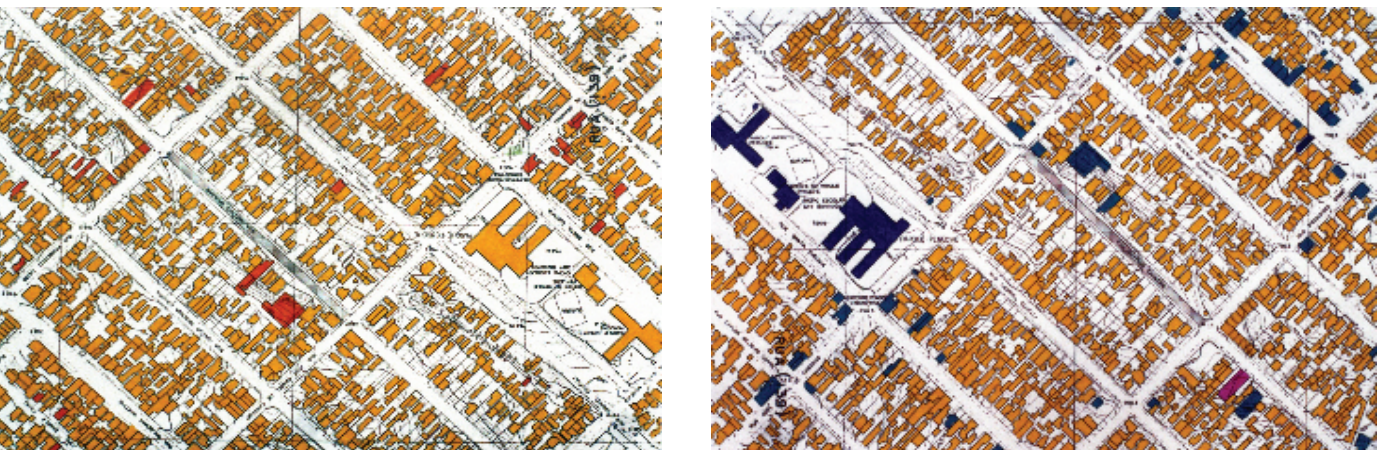

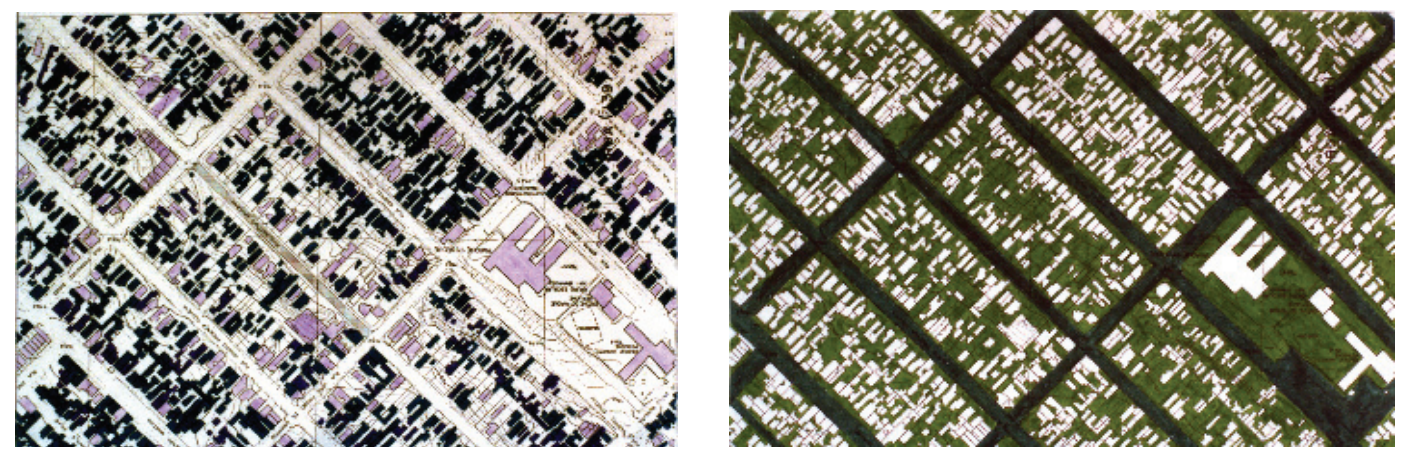

Fotos N:

$\begin{array}{lll}\text { ALTURAS } & 1 \text { a } 2 \text { amarelo } & 9 \text { a } 16 \text { marrom claro } \\ \text { (em pavimentos) } & 3 \text { a } 5 \text { laranja } & +16 \text { marrom escuro } \\ & 6 \text { a } 8 \text { vermelho } & \end{array}$

FUNÇÕES:

Residencial : amarelo

Comercial : azul claro

Institucional : azul escuro

Industrial : rosa maravilha

ESTADO DE

Bom : lilás

CONSERVAÇÃO:

Regular : azul

Ruim : roxo

Público : verde escuro

Particular: verde
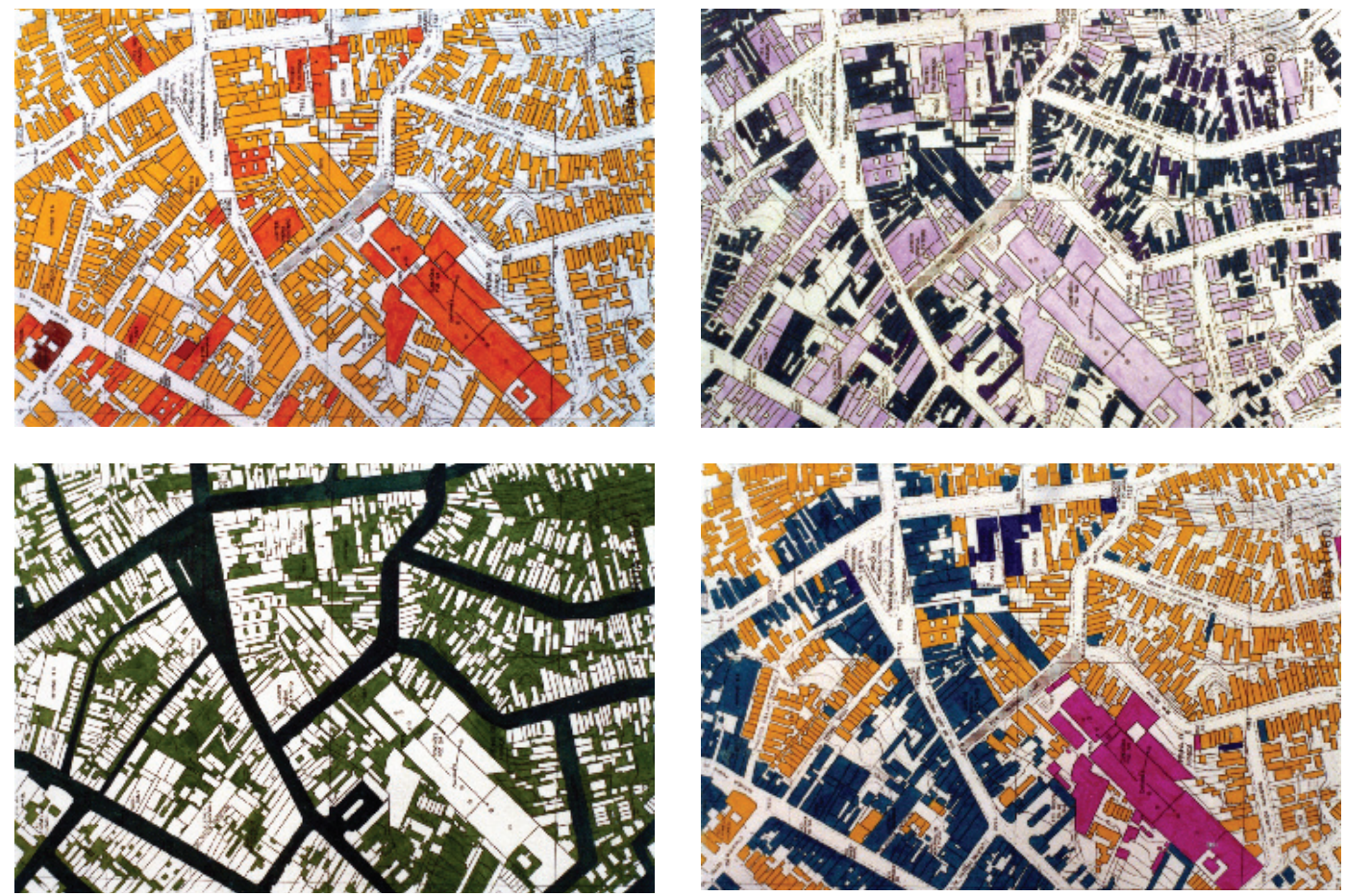
ALTURAS

(em pavimentos)

FUNÇÕES:

ESTADO DE

CONSERVAÇÃO:

ACESSO:
Fotos $\mathrm{O}$ :

$\begin{array}{lll}1 \text { a } 2 & \text { amarelo } & 9 \text { a } 16 \text { marrom claro } \\ 3 \text { a } 5 & \text { laranja } & +16 \text { marrom escuro } \\ 6 \text { a } 8 \text { vermelho } & \end{array}$

Residencial : amarelo

Comercial : azul claro

Institucional : azul escuro

Industrial : rosa maravilha

Bom : lilás

Regular : azul

Ruim : roxo

Público : verde escuro

Particular: verde
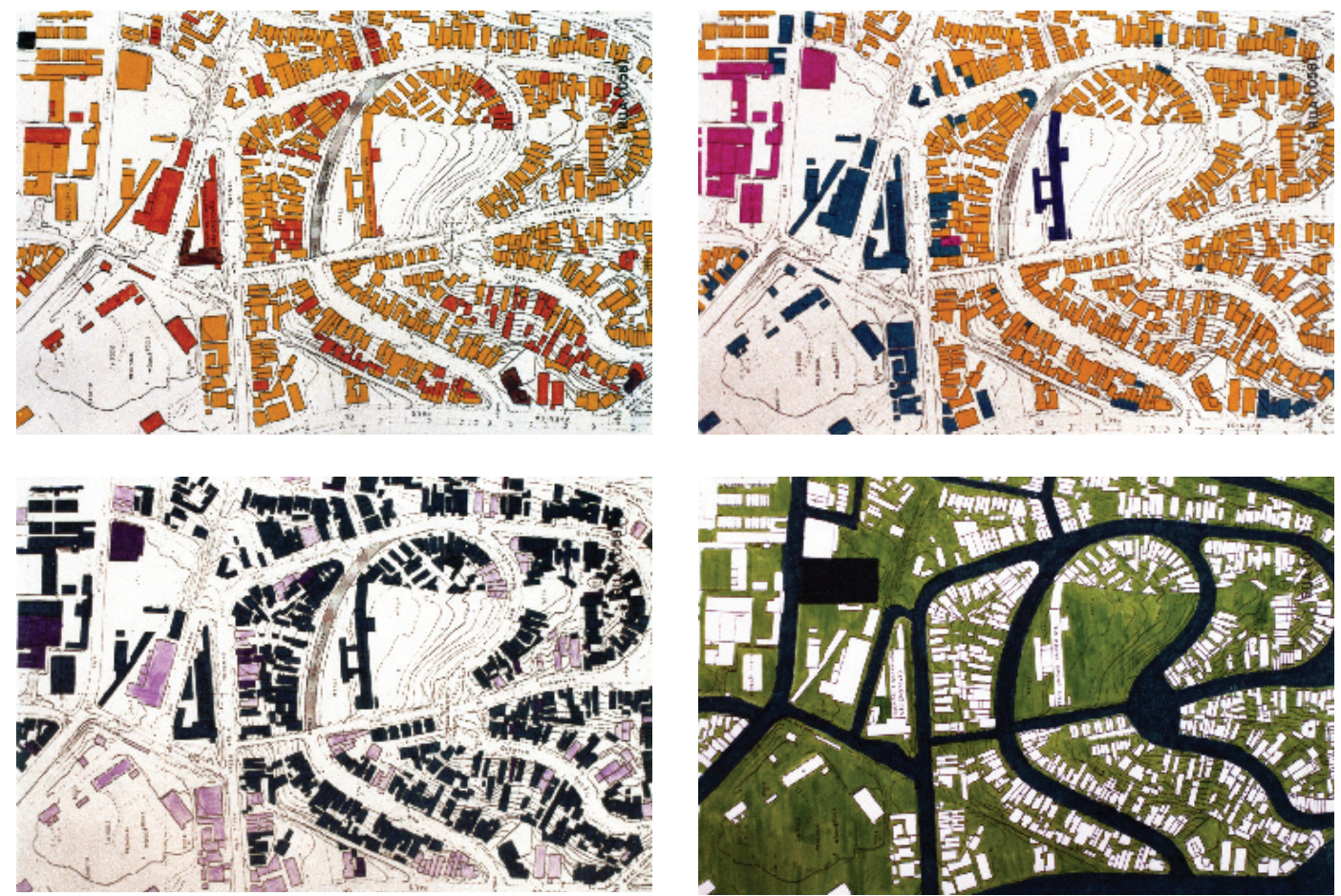

Fotos $\mathrm{P}$ :

ALTURAS

(em pavimentos)

192
1 a 2 amarelo

3 a 5 laranja

6 a 8 vermelho

Residencial : amarelo

Comercial : azul claro

Institucional : azul escuro

Industrial : rosa maravilha 
ESTADO DE

CONSERVAÇÃO:

ACESSO:
Bom : lilás

Regular : azul

Ruim : roxo

Público : verde escuro

Particular : verde
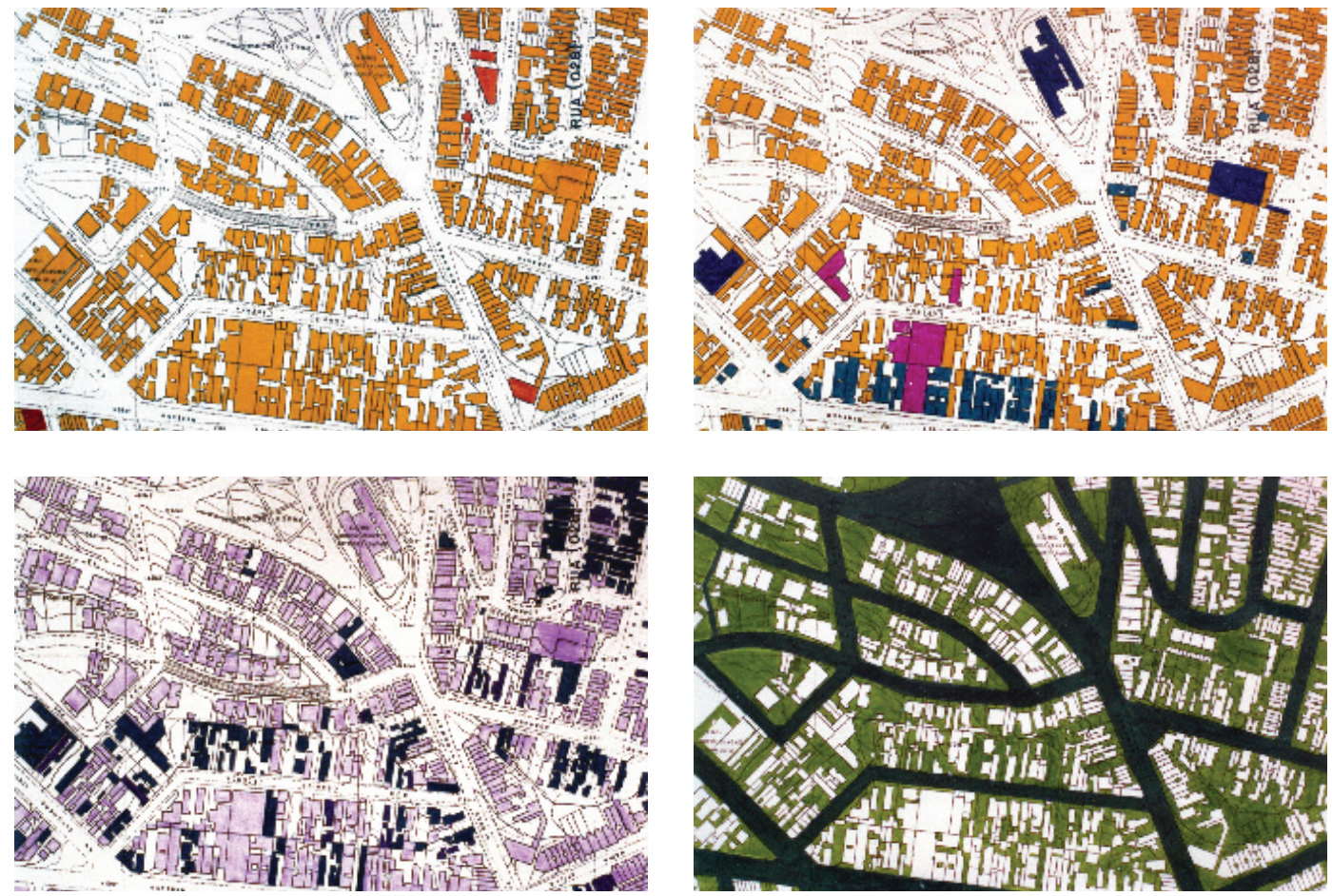

ALTURAS

(em pavimentos)

FUNÇÕES:

ESTADO DE CONSERVAÇÃO:

ACESSO:
Fotos Q:

$\begin{array}{lll}1 \text { a } 2 & \text { amarelo } & 9 \text { a } 16 \text { marrom claro } \\ 3 \text { a } 5 & \text { laranja } & +16 \text { marrom escuro } \\ 6 \text { a } 8 & \text { vermelho } & \end{array}$

Residencial : amarelo

Comercial : azul claro

Institucional : azul escuro

Industrial : rosa maravilha

Bom : lilás

Regular : azul

Ruim : roxo

Particular: verde 

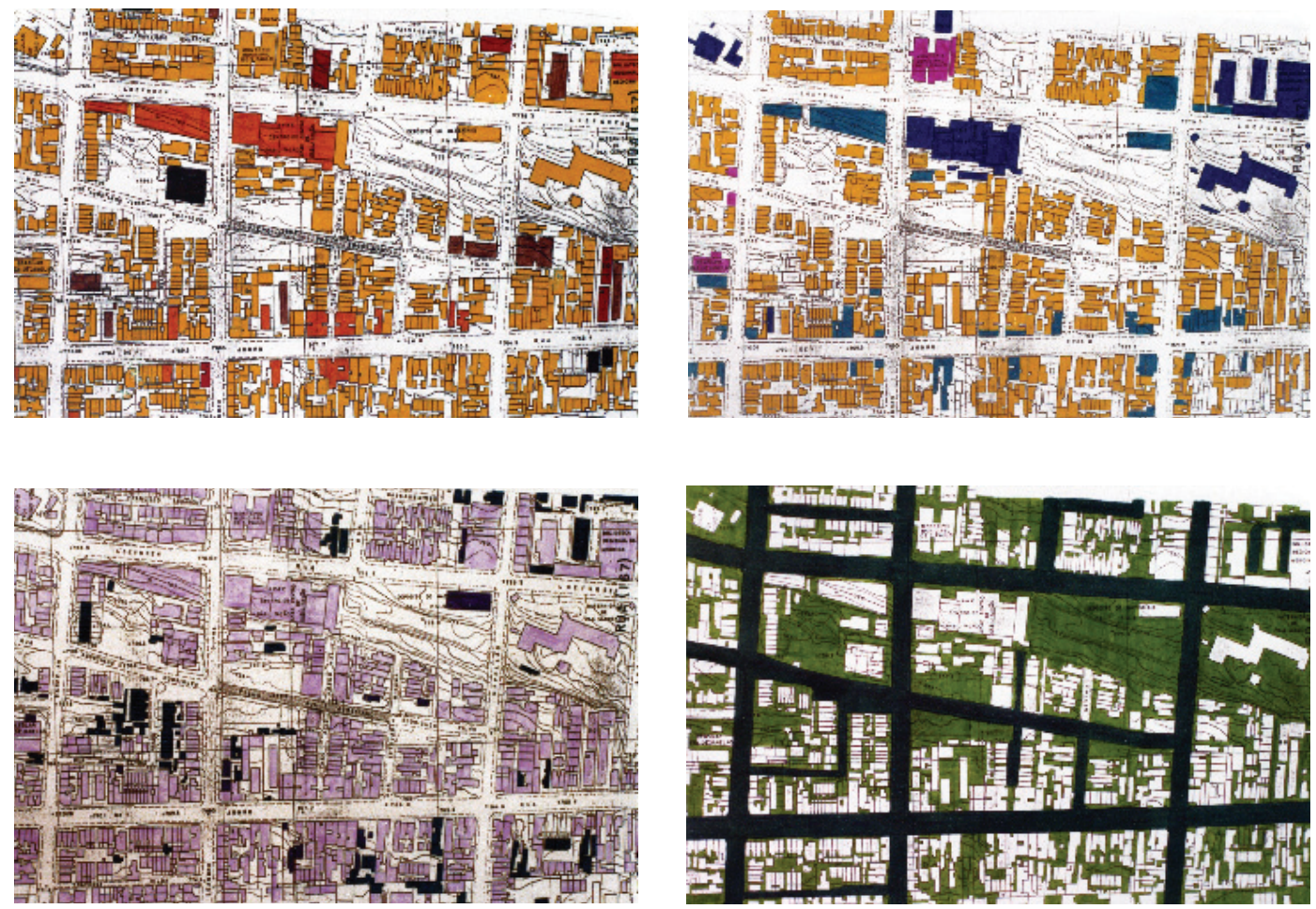

Esses exemplos de parte de levantamento de 18 tipos de tecidos são apresentados de forma visual e diversa de nossa intenção inicial.

Cientes que a Coordenadoria Geral de Planejamento da Prefeitura de São Paulo - Cogep elabora (no início dos anos 1980) sofisticada compilação computadorizada, quarteirão por quarteirão, imaginamos poder contar com elementos os quais, ao fazer a "leitura" do tecido urbano, fornecessem-nos elementos para avaliar o espaço livre. A avaliação seria feita levando em consideração:

Espaços acessíveis

Contigüidade dos edifícios

Alturas
- Em superfície alta

- Em superfície média

- Em superfície baixa

- Muito contíguos

- Medianamente contíguos

- Descontíguos

- Muito descontíguos

- Construções muito altas (acima de 16 pavimentos, maior - $50 \mathrm{~m}$ )

- Construções altas (8 a 16 pavimentos, 30 a $50 \mathrm{~m}$ )

- Construções de altura média (3 a 8 pavimentos - 8 a $30 \mathrm{~m}$ )

- Construções baixas (até 2 pavimentos ou até $8 \mathrm{~m}$ ) 
Aos espaços e à contigüidade se estabeleceriam valores que quantificariam as faixas máximas, mínimas e intermediárias conforme o levantamento das situações máximas e mínimas.

Todavia a compilação da Cogep somente se refere à construção como total da superfície edificada sem elementos referentes à ocupação do solo; já que o espaço livre não é objeto de levantamento e a projeção da edificação no solo e número de pavimentos também não, fica prejudicado o conhecimento das configurações físicas da edificação e do espaço não-edificado.

A procura de elaboração de forma extremamente preliminar, por observação visual comparativa de "manchas" revelou desnecessária qualquer procura, mais aprofundada: O ESPAÇO É SEMPRE QUASE TODO PARTICULAR, independe de alturas, penetração, funções.

O espaço público coletivo, relativo a ruas é sempre muito parecido porque o código não relaciona, especificamente, os volumes edificados, contigüidade e funções com o espaço coletivo. Mais especialmente, o espaço edificado é sempre, em qualquer caso, desenhado para a circulação de veículos.

Consideramos que a aplicação, mesmo de forma rudimentar, das questões exemplificadas nos desenhos (apresentados em fotografias coloridas) anteriores podem indicar situações prioritárias quanto ao espaço livre, algumas alternativas de obtenção de espaço conforme cada caso, cada situação de funções, alturas e o volume e a distribuição de edificações cujo estado de conservação é precário.

A intenção inicial de procurar organizar condições para elaboração de um mapeamento de variação de acessibilidade de espaços livres é fora de propósito. A variação de acessibilidade é muito reduzida, pois o espaço é preponderantemente particular. $\bigcirc$ que existe são variações na quantidade do espaço particular, indicadas pela variação de contigüidades das edificações.

Os levantamentos foram feitos em tecidos, com ruas de lazer que apresentariam poucos espaços livres. Cabe observar que enquanto a utilização da "rua de lazer" é eventual, pelo próprio caráter da implantação, há sempre muitíssimo mais espaço livre particular.

Edificações organizadas de forma articulada com espaço particular e coletivo, público, é para o arquiteto uma questão de desenho ${ }^{26}$.

\section{Notas}

(1) KOSIK, 1976, p. 228.

(2) CLAWSON, 1969, p. 140 (a tradução é nossa).

(3) TANKEL, 1976, p. 42.

(4) É basicamente uma elaboração dessa identificação que subsidia a norma californiana, exposta a seguir.

(5) Citado em TANKEL, 1976, p. 42.

(6) $O$ artigo de TANKEL, 1976 teve forte influência nas origens deste trabalho e de seu enfoque.

(7) Nossa experiência de trabalho em ensino e projetos indica que o espaço livre consciente é referido à circulação de veículos prioritariamente, mesmo onde estes sejam eventuais. $\bigcirc$ arquiteto que trabalha em edificação é, em geral, "cego" para com a existência do espaço livre.

A existência fica dependente de uma tabuleta "praça...". Temos desenvolvido, com alunos de 1ㅇano de graduação, exercícios de percepção da existência.

Da mesma forma é comum entre engenheiros e arquitetos a identificação de espaço da Grande São Paulo com a "mancha urbana".

(8) Divulgação fornecida por CHACEL, Fernando N., em curso de Paisagismo da Associação Brasileira de Arquitetos Paisagistas.

(9) Qualquer pessoa que procure pensar em seus espaços do dia-a-dia observa os mais diversos e variados exemplos. 
(10) SANTOS, Carlos Nelson, 1981, p. 7.

(11) TANKEL, 1976, p. 48.

(12) Para complementação, MONTEIRO, 1980, PASCHOAL, 1981, WELLMAN \& LEIGHTON, 1981 e REMY \& VOYÉ, 1981.

(13) PUSHKAREV \& ZUPAN, 1975, p. 4.

(14) Ibid; 4; os autores indicam para Hong Kong em meados de 1960 superfície líquida de 4,2 m² em habitação de baixa renda.

(15) Para complementação, v. BENÉVOLO, 1979, n. 1, p. 148.

(16) GOLDFINGER, 1970, p. 11.

(17) REIS FILHO, 1970, p. 21.

(18) Idem, p. 26.

(19) Ibidem, p. 50.

(20) PUSHKAREV \& ZUPAN, 1975 p. 7 - os lotes passariam, nas décadas de 1920, 1930 e 1940, de 0,02 he para 0,1 he, em 1950, e 0,2 he em 1960.

(21) BENÉVOLO, 1979, n. 1, p. 159.

(22) MAGNOLI, Experiência de ensino... - a época a que se faz referência no texto é, principalmente, décadas de 1950 e 1960.

(23) Para complementação, v. MAGNOLI, 1982: Notas de aula - Elementos de organização do espaço livre habitacional FAUUSP - Departamento de Projeto e Segre, 1981.

(24) $\bigcirc$ item é uma elaboração nossa sobre o trabalho Tissus, 24, jul. 1971, em que se analisa o tecido urbano em relação às edificações.

(25) Trabalho específico sobre esse tema vem sendo desenvolvido pela arquiteta professora Ayako Nishikawa, de quem sou orientadora. Esse temário não recebe maior aprofundamento neste texto, iá que a pesquisadora autora vem ultimando os estudos para divulgação.

(26) Trabalhos de alunos são desenvolvidos no 1 ano de graduação da FAUUSP, mostrando as possibilidades do desenho sobre os mesmos espaços e as mesmas edificações.

\section{Bibliografia}

BENÉVOLO, Leonardo. Diseño de la ciudad. México: Gili, 1979.

CLAWSON, Marion. Open (uncovered) space as a new urban resource. In: PERLOFF, Harvey (Ed). The quality of the urban environment. Washington: Resources for the future, 1969, p. 139-178.

GOLDFINGER, Myron. Antes de la arquitectura: Edificatión y habitat anónimos en los países mediterráneos. Barcelona: Gili, 1970.

KOSIK, Karel. Dialética do concreto. Rio de Janeiro: Paz e Terra, 1976.

MAGNOLI, Miranda M. E. M. Experiência de ensino de paisagismo para arquitetos na FAUUSP. In: Ensino e pesquisa. São Paulo: FAUUSP, 1981.

Formação do arquiteto que atua na paisagem. In: ENCONTRO TECNOLOGIAS APROPRIADAS PARA OS ASSENTAMENTOS HUMANOS. São Paulo: FAUUSP, 1982

MONTEIRO, Carlos A. F. Environmental problems in São Paulo metropolitan área: The role of urban climate with special focus on flooding IGU-24 ${ }^{\text {th }}$. Tóquio: Tokio International Geographical Congress, 1980.

PASCHOAL, Wanda. As inundações do Cambuci. São Paulo: FFLCH-USP, 1981.

PUSHKAREV, Boris; ZUPAN, Jeffrey M. Urban space for pedestrians. A report of the Regional Plan Association. Cambridge: Mass. MIT, 1975.

REIS Filho, Nestor Goulart. Quadro da arquitetura no Brasil. São Paulo: Perspectiva, 1970.

REMY, Jean; VOYÉ, Liliane. Ville ordre et violence: Formes spatiales et transaction sociale. Paris: Press Universitaires de France, 1981.

196 SANTOS, Carlos Nelson F. Pesquisa sobre uso do solo e lazer no bairro do Catumbi. Rio de Janeiro. Revista SPAM, São Paulo, v. 2, p. 03-12, 1981. 
SEGRE, Roberto. Las estructuras ambientales de América Latina. México: Siglo Veintiuno, 1981.

TANKEL, Stanley. La importancia del espacio libre en el modelo urbano. In: WINGO, L. (Ed). Ciudades y espacio. Barcelona: Barcelona Oikostan, 1976. p. 41-51.

TISSUS URBAINS ET RÈGLEMENTS D'URBANISME. Cahiers de l'institut d'aménagement et d'urbanisme de la région D'lle-de-France. Paris, 1971.

WELLMAN, Barry; LEIGHTON, Barry. Réseau, quartier et communauté: Préliminaire à l'étude de la question communatuaire. Espaces et sociétés. Paris, 1981.

Obs.: Constitui parte do capítulo Il da tese de livre-docência, intitulada Espaços livres e urbanização: Uma introdução a aspectos da paisagem metropolitana, apresentada em 1982 à FAUUSP. 